\title{
Evaluation of Game Addiction, Social Media Addiction and Loneliness Levels in Adolescents with School Attendance Problems
}

\section{Okula Devam Problemi Olan Ergenlerde Sosyal Medya Bağımlılığı, Oyun Bağımlılığı ve Yalnızlık Seviyelerinin Değerlendirilmesi}

\author{
Arif ÖNDER, Özge GİZLİ ÇOBAN, Aslı SÜRER ADANIR, Öznur BİLAÇ, Canem KAVURMA ${ }^{2}$ \\ 1 Department of Child and Adolescent Psychiatry, Akdeniz University School of Medicine, Antalya, Turkey \\ 2 Department of Child and Adolescent Psychiatry, Celal Bayar University School of Medicine, Manisa, Turkey \\ 3 Child and Adolescent Psychiatry Unit, Manisa Mental Health and Diseases Hospital, Manisa, Turkey
}

Yazışma Adresi

Correspondence Address

\section{Arif ÖNDER \\ Department of Child and Adolescent Psychiatry, Akdeniz University School of Medicine, Antalya, Turkey \\ arifonder86@gmail.com}

Geliş tarihi / Received : Aralık 24, 2020 Kabul tarihi / Accepted : Mart 05, 2021 Elektronik yayın tarihi : Ocak 01, 2021 Online published

Bu makalede yapılacak atıf: Cite this article as:

Önder A, Gizli Çoban Ö, Sürer Adanır A, Bilaç Ö, Kavurma C.

Evaluation of Game Addiction,

Social Media Addiction and

Loneliness Levels in Adolescents with School Attendance Problems.

Akd Med J 2022; 8(1):61-67.

\section{Arif Önder}

ORCID 0000-0003-0571-9295

Özge Gizli Çoban

ORCID 0000-0003-4533-105X

Aslı Sürer Adanır

ORCID 0000-0002-6223-756X

Öznur Bilaç

ORCID 0000-0001-8369-6215

Canem Kavurma

ORCID 0000-0003-0086-8726

\begin{abstract}
Objective:

School attendance problem (SAP) is a serious issue, and its coexistence with psychiatric disorders is common. Several studies have evaluated the relationship between SAP and alcohol and substance addiction. Although there are many studies on SAP, studies examining the relationship between SAP and game and social media addiction are limited.
\end{abstract}

\section{Method:}

Thirty-one adolescents with SAP between the ages of 12-19 and 33 age and sex-matched healthy controls were included in the study. Psychopathology was evaluated with a diagnostic interview according to DSM 5. Internet Gaming Disorder Scale-Short Form (IGDS9-SF), Social Media Disorder Scale and UCLA Loneliness Scale were given to both of the groups.

Results:

The most common disorders in the study group are attention deficit hyperactivity disorder, oppositional disorder and behavioral disorder. In the study group, the UCLA Loneliness Scale and IGDS9-SF scores were also significantly higher than those in the controls.

\section{Conclusion:}

Game addiction and loneliness problems should also be examined in the evaluation of children and adolescents with school attendance problems.

Key Words: School Attendance Problem, School Refusal, Game Addiction, Social Media Addiction, Loneliness

ÖZ

Amaç:

Okula devam problemleri (ODP) çok sayıda psikiyatrik rahatsızlıkla birliktelik gösterebilen ciddi bir sorundur. ODP ile alkol ve madde bağımlılığını değerlendiren çalışmalar mevcuttur. ODP ile ilgili çok sayıda çalışma yapılmasına rağmen ODP'nin oyun ve sosyal medya bağımlılı̆̆ ile ilişkisini inceleyen çalışma sayısı kısıtlıdır. 


\section{Yöntem:}

Çalışmaya 12-19 yaş arasında olup ODP olan 31 ergen ile yaş ve cinsiyet olarak eşleştirilmiş 33 sağlıklı kontrol dahil edilmiştir. Çalışma grubunda psikopatoloji, DSM 5'e göre düzenlenmiş tanısal görüşme ile değerlendirilmiştir. Her iki grubu da İnternet oyun oynama bozukluğu ölçeği kısa formu (İOBS9-KF), Sosyal medya bağımlılık ölçeği kısa formu ve UCLA yalnızlık ölçeği uygulanmıştır.

\section{Bulgular:}

Çalışma grubunda en sık dikkat eksikliği hiperaktivite bozukluğu, karşı olma karşı gelme bozukluğu ve davranım bozukluğu tanıları saptanmıştır. Çalışma grubunda kontrol grubuna göre UCLA yalnızlık ölçeği ve İOBS9-KF puanları anlamlı olarak yüksek bulunmuştur.

\section{Sonuç:}

Okula devam problemleri olan çocuk ve ergenlerin değerlendirilmesinde oyun bağımlılığı ve yalnızlık sorunları da sorgulanmalidir.

Anahtar Sözcükler: Okula devam problemleri, Okul reddi, Oyun bağımlılığı, Sosyal medya bağımlılığı, Yalnızlık

\section{INTRODUGTION}

School attendance problems (SAP) have been the focus of interest from the beginning of the 20th century. Numerous studies have been conducted since Broadwin first described the symptoms in 1932 (1). Despite almost a century of SAP history, there is no consensus on its definition and classification. There are many terms used in different ways and meanings, such as skipping school, avoiding school, school phobia and SAP. Among these terms, SAP is most frequently used. It refers to situations in which a child cannot attend school for any reason and cannot stay in the classroom even if he/she attends. It includes concepts such as school refusal, truancy and school withdrawal $(2,3)$. Although there are many definitions for SAP in the literature, the definition proposed by Kearny is one of the most recent. It includes two main criteria: 1- For at least 2 weeks, missing at least $25 \%$ of total school time, 2- Having serious difficulty in attending classes for at least 2 weeks in a way that significantly disrupts the daily routine of the child and family. A third criterion added to these criteria is the absence of a total of at least 10 days for 15 weeks while the school is open (4). Another concept, school refusal, is defined as school avoidance within the knowledge of the parents due to the child's anxiety and negative emotions. Truancy is defined as the child not going to school without any valid justification $(5,6)$.

School refusal occurs in $1-5 \%$ of all school children. Its frequency peaks at the ages of 5-7, 11 and 14. It is seen in all socioeconomic classes, and girls and boys are affected equally (7).

Children and adolescents with SAP are also at risk for many mental, emotional, social and academic disorders (8). There is a correlation between school refusal and psychiatric disorders such as anxiety and depression (9).
In a study conducted by Havik et al. on 5465 students from 45 schools, poor relationships with peers were found to be an important risk factor for school refusal (10).

Nowadays, game addiction, excessive gameplay and video game addiction are frequently used terms for excessive game playing (11). Although it is not an official diagnosis, Internet gaming disorder is included in DSM-5 in the section of the manual known as "Conditions for Further Study," and this disorder is frequently seen in 12 to 20-year-old men (12). Internet game playing disorder has been defined as repetitive internet gaming, leading to clinically significant impairment or distress. The diagnostic criteria (similar to those for substance addiction) include excessive mental involvement in playing games, withdrawal symptoms, unsuccessful attempts to control the gaming behaviour and loss of interest in other activities (12). The risk of game addiction is higher among young people who spend most of their leisure time with video games (13). The frequency of online game addiction varies between $2.2 \%$ and $12 \%$, depending on the method chosen and study design (14). Video game addiction affects children, adolescents and adults in many areas. A significant relationship was found between violent games and aggression (15). Moreover, it can lead to consequences such as unhappiness, anxiety, decreased academic success and loneliness (16). Game addiction was found to be associated with depression, behavioural problems, obesity and related conditions $(17,18)$.

Children and adolescents spend an important part of their leisure time on social media networks such as Facebook, Twitter and Instagram. While girls use social media more often, boys mostly prefer playing video games $(19,20) \mathrm{A}$ vast majority of adolescents aged 13-17 sign in to their social media accounts more than once a day (20). There are no generally accepted criteria for social media addiction/overuse yet. Even so, there are different definitions, such as Facebook addiction, Twitter addiction and social media addiction (21). Although the diagnostic criteria are not determined precisely, many studies have shown the social media addiction's effects on children and adolescents. Excessive social media use is associated with a decrease in academic success, low self-esteem and deterioration in peer relations (22-24). Moreover, it is also related to psychiatric disorders such as attention deficit hyperactivity disorder (ADHD), obsessive compulsive disorder, anxiety and depression (25).

Loneliness levels were higher in children with SAP than in those without SAP (26). Individuals who were lonely or lacked appropriate social skills could develop Internet use behaviours in a strong compulsive pattern, which may result in negative life outcomes (27). Loneliness was evaluated in our study because it affects both school rejection and game-playing behaviour.

Several studies have evaluated the relationship between SAP and alcohol and substance addiction. Although there is no chemical intake in online game addiction, excessive game playing can lead to physical dependence and changes in brain activity like other addictive substances. We hypothesized that 
adolescents with SAP have more game addiction, social media addiction and higher loneliness levels than their counterparts without SAP.

\section{MATERIAL and METHODS}

Participants: Thirty-one adolescents between the ages of 12-19 who met the criteria for SAP by Kearny, and 33 healthy controls who did not meet the SAP criteria and had no previous psychiatric application were included in the study. The study group was selected from patients who applied to our outpatient clinic from May 2019 to February 2020. The cohort of SAP participants in our study consisted of children who attended school without exhibiting difficulties until adolescence, at which time the issue of school refusal became apparent. As the study aims to examine the school attendance problems beginning in adolescence, children who exhibited attendance problems since they began to elementary school were not included. Children who were unable to attend school due to health problems or unwilling parents were also excluded. Adolescents who did not have any school attendance problems and did not apply to a child-adolescent psychiatry outpatient clinic before were included as the control group. The study group was compared with healthy controls for game addiction, social media addiction and loneliness. All the children participating in the study were evaluated with a diagnostic interview according to DSM 5 by a child and adolescent psychiatrist with at least 5 years of clinical experience in the field; the scales described below were applied.

\section{Measures:}

Sociodemographic form: Sociodemographic data including age, sex, socioeconomic level, parent-reported school achievement, duration of school absenteeism and academic grade were noted by researchers.

\section{The Internet Gaming Disorder Scale - Short Form (IGDS9-SF):}

The IGDS9-SF scale was developed by Pontes and Griffiths in 2015 (28). Aricak et al. proved its validity and reliability for use in the Turkish population (29). It is a 5-point Likert self report scale consisting of nine items referring to the nine criteria proposed in DSM-5. Increasing scores in the scale indicate that the severity of internet game addiction has increased.

\section{Social Media Disorder Scale (SMDS):}

SMDS is a yes/no scale developed by van den Eijnden et al., consisting of 9 items (30). Tas demonstrated its validity and reliability for use in the Turkish language (31). A yes answer is coded as 1 point, and no point is deducted for a no answer. It is a self-report scale, and increasing scores indicate that the severity of social media addiction increases.

\section{UCLA Loneliness Scale:}

It is consisted of 20-items and used to measure one's subjective feelings of social isolation and loneliness levels. It was developed by Russel et al. in 1978 and revised in 1980 (32,
33). Demir proved its validity and reliability for use in the Turkish population (34). The score obtained from the scale varies from 20-80. An increase in scale points indicates an increase in the loneliness level of the participant.

\section{Statistical analysis:}

SPSS 20 was used for statistical analysis. T-test or Mann-Whitney U test was used to compare the scale scores of the groups, and the chi-square method was used to identify the differences between the frequences of discrete data. Spearman test was used for correlation evaluation. The statistical significance level was accepted as $\mathrm{p}<0.05$.

\section{RESULTS}

The study included 31 patients and 33 healthy controls. There was no significant difference between groups for age, gender, mother's age, father's age, mother's education, father's education and family income (Table I). Absenteeism of children with SAP in the last 30 school days was $13.81 \pm 6.23$ days. They attended school irregularly for an average of 7.98 months (long term holidays such as summer vacation and semester break were not included in the calculation of this period). Academic success and academic grade were found to be statistically significant between 2 groups (Table I).

Table I: Comparison of Study and Control groups in terms of sociodemographic data

\begin{tabular}{|c|c|c|c|}
\hline & $\begin{array}{c}\text { Patient group } \\
(\mathrm{n}=31)\end{array}$ & $\begin{array}{l}\text { Control group } \\
(\mathrm{n}=33)\end{array}$ & $\mathrm{P}$ \\
\hline $\begin{array}{l}\text { Sex } \\
(\text { male/female })^{\mathrm{a}} \\
(\mathrm{N} / \%)\end{array}$ & $23 / 8(\% 74.2 / 25.8)$ & $19 / 14(\% 57.6 / 42.4)$ & 0.195 \\
\hline $\begin{array}{l}\mathrm{Age}^{\mathrm{b}} \\
(\text { Median+Q1-Q3) }\end{array}$ & $14(13-15)$ & $16(13-17)$ & 0.145 \\
\hline $\begin{array}{l}\text { Academic grade } \\
\text { (Median+Q1-Q3) }\end{array}$ & $8(7-10)$ & $11(8.25-12)$ & 0.018 \\
\hline $\begin{array}{l}\text { Academic } \\
\text { success }^{1-a}\end{array}$ & $8 / 11 / 12$ & $13 / 17 / 1$ & 0.003 \\
\hline $\begin{array}{l}\text { Absenteeism in } \\
\text { the last } 30 \text { school } \\
\text { days } \\
\text { (Median+Q1-Q3) }\end{array}$ & $16(8-20)$ & $1(1-3)$ & $<0.001$ \\
\hline $\begin{array}{l}\text { Mother's age } \\
\text { (Median+Q1-Q3) }\end{array}$ & $42(39.25-48)$ & $40(37-43)$ & 0.080 \\
\hline $\begin{array}{l}\text { Father's age } \\
\text { (Median+Q1-Q3) }\end{array}$ & $45.50(39-50.25)$ & $44(39.5-47)$ & 0.531 \\
\hline $\begin{array}{l}\text { Mother's } \\
\text { education }^{2-a}\end{array}$ & $14 / 7 / 5$ & $10 / 15 / 3$ & 0.135 \\
\hline $\begin{array}{l}\text { Father's } \\
\text { education }^{2-a}\end{array}$ & $9 / 11 / 5$ & $8 / 16 / 4$ & 0.628 \\
\hline Family Income $e^{3-a}$ & $7 / 16 / 8$ & $8 / 18 / 4$ & 0.472 \\
\hline $\begin{array}{l}\text { BMI } \\
\text { (Median+Q1-Q3) }\end{array}$ & $\begin{array}{l}21.61 \\
(20.08-24.72)\end{array}$ & $\begin{array}{l}21,98 \\
(19.50-23.23)\end{array}$ & 0,768 \\
\hline
\end{tabular}

1Good/moderate/bad, 2 Primary school/secondary school-high scool/ University

3 Below the minimum wage/above the minimum wage but less than twice the minimum wage/ those who have more than twice the minimum wage.

a Chi Square b Mann Whitney U 
In the group with SAP, ADHD was the most common diagnosis, followed by oppositional defiant disorder, conduct disorder and major depression. Table II shows all diagnoses with their rates.

Table II: Psychiatric disorders in the study group

\begin{tabular}{|l|l|}
\hline Psychiatric disorders & N(\%) \\
\hline Attention deficit hyperactivity disorder & $13(\% 41.9)$ \\
\hline Oppositional defiant disorder & $8(\% 25.8)$ \\
\hline Conduct disorder & $7(\% 22.5)$ \\
\hline Major depression & $6(\% 19.3)$ \\
\hline Generalized anxiety disorder & $4(\% 12.9)$ \\
\hline Social anxiety disorder & $3(\% 9.6)$ \\
\hline Enuresis & $2(\% 6.5)$ \\
\hline Substance abuse & $1(\% 3.23)$ \\
\hline Bipolar affective disorder & $1(\% 3.23)$ \\
\hline Obsessive compulsive disorder & $1(\% 3.23)$ \\
\hline
\end{tabular}

Game addiction and loneliness levels were significantly higher in the study group compared to control group. There was no significant difference between groups for social media addiction (Table III).

Table III: Comparison of Study and Control groups in terms of scale scores a T Test, b Mann Whitney U

\begin{tabular}{|l|l|l|l|l|}
\cline { 2 - 5 } \multicolumn{1}{c|}{} & $\begin{array}{l}\text { Patient group } \\
(\mathrm{n}=31)\end{array}$ & $\begin{array}{l}\text { Control group } \\
(\mathrm{n}=33) \\
\text { Mean } \pm \mathrm{SD}\end{array}$ & t or $\mathrm{z}$ & $\mathrm{p}$ \\
\hline $\begin{array}{l}\text { IGDS9-SF } \\
\text { scores } \\
\left.\text { (Mean }^{\mathrm{a}} \pm \text { SD }\right)\end{array}$ & $25.29 \pm 8.46$ & $16.06 \pm 5.56$ & 5.13 & $<0.001$ \\
\hline $\begin{array}{l}\text { SMDS scores } \\
\text { (Median+Q1- } \\
\text { Q3) }\end{array}$ & $4(1-6)$ & $2(0-4)$ & -1.88 & 0.061 \\
\hline $\begin{array}{l}\text { UCLA scores } \\
\text { (Median+ }+\mathrm{Q} 1-\end{array}$ & $\begin{array}{l}56.00 \\
\text { Q3) }\end{array}$ & $34(27.50-40)$ & -4.51 & $<0.001$ \\
\hline
\end{tabular}

a T Test, b Mann Whitney U

A positive correlation was found between absenteeism frequency and game addiction and loneliness. There was also a positive correlation between social media addiction and IGDS9-SF scores. (Table IV).

Table IV: Correlation coefficients of study variables

\begin{tabular}{l|c|c|c|c|c|}
\hline & $\mathbf{1}$ & $\mathbf{2}$ & $\mathbf{3}$ & $\mathbf{4}$ & $\mathbf{5}$ \\
\hline $\begin{array}{l}\text { 1-Absenteeism } \\
\text { frequency }\end{array}$ & - & - & - & - & - \\
\hline 2-Academic success & -0.25 & - & - & - & - \\
\hline 3- IGDS9-SF scores & $0.35^{* *}$ & $-0.28^{*}$ & - & - & - \\
\hline 4- SMDS scores & 0.13 & -0.24 & $0.27^{*}$ & - & - \\
\hline 5-Ucla scores & $0.42^{* *}$ & -0.07 & 0.25 & 0.20 & - \\
\hline
\end{tabular}

\footnotetext{
Spearman correlation analysis, ${ }^{*} \mathrm{P}<0.05,{ }^{*} \mathrm{P}<0.01$
}

In the study group, a comparison of game addiction, social media addiction and loneliness levels for gender showed that game addiction was significantly higher in boys than in girls (boys/girls (mean and standard deviation): $27.91 \pm$ 7.57/17.75 $\pm 6.25, \mathrm{Z:-2.89}$ p: 0.004).

\section{DISGUSSION}

Although many studies have evaluated the reasons for SAP, no study has examined its relationship with game addiction and social media addiction. Although SAP is not included as a separate diagnosis in DSM-5, Internet gaming disorder takes place in the section of the manual known as "Conditions for Further Study." DSM has identified 9 criteria. The 9th criterion emphasised that Internet gaming disorder may negatively impact education $(12,35)$.

According to a model developed by Kearney and Silverman to understand SAP, negative reinforcers such as avoiding situations that cause anxiety in school, or social conditions and/or positive reinforcers such as having an enjoyable time when not attending school, receiving tangible benefits or gaining parents' attention have been effective in school refusal behaviour. The pleasure that video games create in the child during the game can also be a positive reinforcer for school refusal. Studies show that reinforcers such as watching TV and having fun at home during school time worsen $\operatorname{SAP}(8,36)$.

Several studies have evaluated the relationship between SAP and addiction. Research reveals that skipping school is a significant risk factor for alcohol, cigarette and marijuana use (37). Hallfors et al. showed that students with higher school absenteeism and below-average graduation degrees were more likely to use cigarettes, alcohol and marijuana than other students. Moreover, they were more prone to get involved in crime and attempt suicide (38). Although there is no chemical intake in online game addiction, excessive game playing can lead to physical dependence and changes in brain activity like other addictive substances (39). SAP may cause alcohol and substance addiction and increase the risk of game addiction. In our study, the high level of game addiction in the study group can be explained with these findings.

Research shows a relationship between the time spent in game-playing and academic achievement in high school students (40). Similarly, a negative correlation between academic success and game addiction scores was found in our study. A study conducted by Carroll showed a correlation between absenteeism for a school term and a decrease in reading and math test scores in 7 to 11 -year-old children (41). Gottfried demonstrated that unexcused absence caused a drop in reading and math test scores (42). Anand et al. observed that there was a negative correlation between the amount of time spent on playing video games and students' grade-point average and Scholastic Aptitude Test scores (43).

The study group showed higher SMDS scores than the control group, but this difference did not reach a statistically significant level. Young people use social media for different purposes, such as meeting their friends, messaging, playing games, meeting new people and sharing photos (21). 
Although the use of social media brings many risks, it can also be useful for improving the communication skills of children and adolescents, increasing their knowledge and expanding their social network. The use of social media may not result in SAP for this reason. However, video games may result in school refusal as they increase social isolation. Social media addiction was also high in the control group $(18 \%)$. Thus, a high rate of social media addiction was found not only in the SAP group but also in the control group.

Another important difference between the study group and the control group was the level of loneliness. In the study group, loneliness levels were found to be significantly higher. Similarly, Havik et al.'s study on 5465 students from 45 schools showed that poor relationships with peers were important risk factors for school refusal (10). A study conducted on 1009 high school students revealed that loneliness was associated with many psychiatric symptoms and disorders such as depression, anxiety, social phobia, suicidal thoughts, self-injurious behaviour and eating disorders (44). In another study, Odacı and Kalkan found a positive correlation between problematic internet use and loneliness levels (45). A study examining loneliness and SAP demonstrated that children with SAP had difficulties in peer relationships and felt more alone (46). Loneliness can lead to school rejection and increased game-play behaviour. The lonely children will be disrupted from school, which will cause them to play more games. An increased amount of time spent playing games may worsen feelings of loneliness (47).

An examination of the diagnoses in the study group showed that ADHD and disruptive behaviour disorders (conduct disorder and oppositional defiant disorder) were leading the pack. Considering the studies examining the relationship between school refusal and psychopathology, Egger et al. reported that patients with mixed type of school refusal showed significantly high conduct disorder, ADHD, oppositional defiant disorder and substance use (48). Andreassen and colleagues noted a significant relationship between game addiction and ADHD (25). In a study conducted by Egger et al., the rate of a comorbid psychiatric disorder was found in $88.2 \%$ of the children with anxiety-based school refusal and truancy. Anxiety-based school refusal was associated with separation anxiety and depression. Truancy was associated with disruptive behaviour disorders and depression (48).

In our study, the rate of anxiety disorders was relatively low. One explanation for this finding may be that our study group consisted of secondary school students. Anxiety-based school refusal usually starts at an earlier age $(48,49)$. The mean age of our study group was 14.26 years, which may result in fewer anxiety disorders and more disruptive behavioural disorders. In addition, excluding school refusals beginning in primary school period may have caused a decrease in the rate of anxiety disorders.

In our study, game addiction scale scores were higher in boys than in girls. This finding is consistent with the research of Andreassen et al. that being female was significantly associ- ated with the a use of social media; being male was significantly associated with the problematic use of video games (25).

\section{GONGLUSIONS}

In our study, particularly game addiction and loneliness levels were higher in the study group. It would be useful to focus on these two factors in the evaluation and treatment of school refusals.

There are strengths and limitations of the study. To the best of our knowledge, this is the first study examining the relationship between SAP and Internet gaming disorder. The most important limitation of our study is its cross-sectional nature. It is difficult to predict whether game addiction is the cause or result of SAP. Therefore, follow-up studies are imperative. The study was also limited by its small sample size. An important reason could be that students who were rarely absent from school were not included. In our study, the mean duration of absenteeism was 13.93 days in the last month. The mean period since the beginning of the absenteeism was approximately 8 months. Working with a group that was absent for such a long time and not dismissed from school led to a decrease in our sample size.

\section{Declarations:}

Ethics Committee Approval: Ethics approval and Consent to participate: Approval was obtained from the Akdeniz University Faculty of Medicine Clinical Research Ethics Committee for the study (2019/368). This study was conducted in accordance with the Helsinki Declaration. All children and parents participating in the study were given information about the study, and the parents provided written consent.

Informed Consent: According to the Helsinki Declaration, all the rights of the participants were protected and written informed consents were obtained before the procedures.

Author Contributions: Concept-AÖ, ÖGÇ, ASA; Design AÖ, ÖGÇ, ASA, CK, ÖB; Supervision - ASA; Resources -AÖ, ÖGÇ, ASA, CK, ÖB Materials - AÖ, ÖGÇ, ASA, CK, ÖB; Data Collection and/or Processing - AÖ, CK, ÖB Analysis and/ or Interpretation - AÖ, ÖGÇ; Literature Search - AÖ, ÖGÇ, ASA, ÖB; Writing Manuscript - AÖ, ÖGÇ, ASA; Critical Review - ÖG, CK, ÖB.

Conflict of Interest: The authors declared that there is no conflict of interest.

Financial Disclosure: No financial support has received for this study. 
Önder A.et al

\section{REFERENGES}

1. Broadwin IT. A contribution to the study of truancy. Am J Orthopsychiatry 1932; 2:253.

2. Kearney CA, Turner II D, and Gauger M. School Refusal Behavior. In: The Corsini Encyclopedia of Psychology. American Cancer Society 2010; 1-2.

3. Heyne D, Gren-Landell M, Melvin G, and Gentle-Genitty C. Differentiation between school attendance problems: why and how? Cogn Behav Pract 2019; 26:8-34.

4. Kearney CA. An interdisciplinary model of school absenteeism in youth to inform professional practice and public policy. Educ Psychol Rev 2008; 20:257-282.

5. Kearney CA. The evolution and reconciliation of taxonomic strategies for school refusal behavior. Clin Psychol Sci Pract 1996; 3:339-354.

6. Sutphen RD, Ford JP, and Flaherty C. Truancy interventions: A review of the research literature. Res Soc Work Pract 2010; 20:161-171.

7. Heyne D, King NJ, Tonge BJ, and Cooper H. School refusal: epidemiology and management. Paediatr Drugs 2001; 3:719-732.

8. Dube SR and Orpinas P. Understanding excessive school absenteeism as school refusal behavior. Child Sch 2009; 31:87-95.

9. Fremont WP. School refusal in children and adolescents. Am Fam Physician 2003; 68:1555-1560.

10. Havik T, Bru E, and Ertesvåg SK. School factors associated with school refusal-and truancy-related reasons for school non-attendance. Soc Psychol Educ 2015; 18:221-240.

11. Griffiths M. Internet and video-game addiction. In: Adolescent Addiction. Elsevier 2008; 231-267.

12. Association AP. Diagnostic and statistical manual of mental disorders (DSM-5®). American Psychiatric Pub 2013: 175 .

13. Grüsser SM, Thalemann R, and Griffiths MD. Excessive computer game playing: evidence for addiction and aggression? Cyberpsychology Behav 2006; 10:290-292.

14. Kuss DJ and Griffiths MD. Internet gaming addiction: A systematic review of empirical research. Int $\mathrm{J}$ Ment Health Addict 2012; 10:278-296.

15. Anderson CA and Carnagey NL. Causal effects of violent sports video games on aggression: Is it competitiveness or violent content? J Exp Soc Psychol 2009; 45:731-739.

16. Gentile DA, Choo H, Liau A, Sim T, Li D, Fung D, et al. Pathological video game use among youths: a two-year longitudinal study. Pediatrics 2011; 127:e319-e329.

17. Vandewater EA, Shim M, and Caplovitz AG. Linking obesity and activity level with children's television and video game use. J Adolesc 2004; 27:71-85.

18. Brunborg GS, Mentzoni RA, and Frøyland LR. Is video gaming, or video game addiction, associated with depression, academic achievement, heavy episodic drinking, or conduct problems? J Behav Addict 2014; 3:27-32.

19. Ahn J. The effect of social network sites on adolescents' social and academic development: Current theories and controversies. J Am Soc Inf Sci Technol 2011; 62:1435-1445.

20. Lenhart A, Duggan M, Perrin A, Stepler R, Rainie H, and Parker K. Teens, social media \& technology overview 2015. Pew Research Center [Internet \& American Life Project]; 2015.

21. Bányai F, Zsila Á, Király O, Maraz A, Elekes Z, Griffiths $\mathrm{MD}$, et al. Problematic social media use: Results from a large-scale nationally representative adolescent sample. PLoS One 2017; 12:e169839.

22. Wegmann E, Stodt B, and Brand M. Addictive use of social networking sites can be explained by the interaction of Internet use expectancies, Internet literacy, and psychopathological symptoms. J Behav Addict 2015; 4:155-162.

23. Malik S and Khan M. Impact of facebook addiction on narcissistic behavior and self-esteem among students. J Pak Med Assoc 2015; 65:260-263.

24. Akhter N. Relationship between internet addiction and academic performance among university undergraduates. Educ Res Rev 2013; 8:1793-1796.

25. Andreassen CS, Billieux J, Griffiths MD, Kuss DJ, Demetrovics Z, Mazzoni E, et al. The relationship between addictive use of social media and video games and symptoms of psychiatric disorders: A large-scale cross-sectional study. Psychol Addict Behav 2016; 30:252.

26. Romani J, Campredon S, and Da Fonseca D. School refusal: Psychopathological profiles of adolescents 
followed in a day hospital setting. Arch Pediatr Organe Off la Soc Fr Pediatr 2017; 24:950-959.

27. Kim J, LaRose R, and Peng W. Loneliness as the cause and the effect of problematic Internet use: The relationship between Internet use and psychological well-being. Cyberpsychology Behav 2009; 12:451-455.

28. Pontes HM and Griffiths MD. Measuring DSM-5 Internet gaming disorder: Development and validation of a short psychometric scale. Comput Human Behav 2015; 45:137-143.

29. Arıcak OT, Dinç M, Yay M, and Griffiths MD. Adapting the Short Form of the Internet Gaming Disorder Scale into Turkish: Validity and Reliability. Addicta Turkish J Addict 2018; 5:615-636.

30. Van Den Eijnden RJJM, Lemmens JS, and Valkenburg PM. The social media disorder scale. Comput Human Behav 2016; 61:478-487.

31. Taş İ. The Social Media Addiction Scale (SF) for Adolescents: A Study of Validity and Reliability. Online J Technol Addict Cyberbullying 2017; 4:27-40.

32. Russell D, Peplau LA, and Ferguson ML. Developing a measure of loneliness. J Pers Assess 1978; 42:290-294.

33. Russell D, Peplau LA, and Cutrona CE. The revised UCLA Loneliness Scale: concurrent and discriminant validity evidence. J Pers Soc Psychol 1980; 39:472.

34. Demir A. UCLA yalnızlık ölçeğinin geçerlik ve güvenirliği (Validity and reliability of the UCLA loneliness scale). Psikol Derg 1989; 7:14-18.

35. Adanır AS, Özatalay E, and Doğru H. Oyuna adanmış yaşam: Bir olgu sunumu üzerinden internet oyun oynama bozukluğuna kısa bir bakış (Life commited to game: A short look to internet gaming disorder upon a case report). Turkish J Fam Pract 2016; 20:85-90.

36. Kearney CA and Silverman WK. Measuring the function of school refusal behavior: The School Refusal Assessment Scale. J Clin Child Psychol 1993; 22:85-96.

37. Henry KL and Huizinga DH. Truancy's effect on the onset of drug use among urban adolescents placed at risk. J Adolesc Heal 2007; 40:358-e9.

38. Hallfors D, Cho H, Brodish PH, Flewelling R, and Khatapoush S. Identifying high school students "at risk" for substance use and other behavioral problems: Implications for prevention. Subst Use Misuse 2006; 41:1-15.
39. Dong G, Hu Y, and Lin X. Reward/punishment sensitivities among internet addicts: implications for their addictive behaviors. Prog Neuro-Psychopharmacology Biol Psychiatry 2013; 46:139-145.

40. Harris MB and Williams R. Video games and school performance. Education 1985; 105.

41. Carroll HCM. The effect of pupil absenteeism on literacy and numeracy in the primary school. Sch Psychol Int 2010; 31:115-130.

42. Gottfried MA. Excused versus unexcused: How student absences in elementary school affect academic achievement. Educ Eval Policy Anal 2009; 31:392-415.

43. Anand V. A study of time management: The correlation between video game usage and academic performance markers. CyberPsychology Behav 2007; 10:552-559.

44. Lasgaard M, Goossens L, Bramsen RH, Trillingsgaard T, and Elklit A. Different sources of loneliness are associated with different forms of psychopathology in adolescence. J Res Pers 2011; 45:233-237.

45. Odac $\mathrm{H}$ and Kalkan M. Problematic Internet use, loneliness and dating anxiety among young adult university students. Comput Educ 2010; 55:1091-1097.

46. Jones AM and Suveg C. Flying under the radar: School reluctance in anxious youth. School Ment Health 2015; 7:212-223.

47. Lee J, Ko DW, and Lee H. Loneliness, regulatory focus, inter-personal competence, and online game addiction. Internet Res 2019.

48. Egger HL, Costello JE, and Angold A. School refusal and psychiatric disorders: A community study. J Am Acad Child Adolesc Psychiatry 2003; 42:797-807.

49. Bahali K, Tahiroğlu AY, and Avci A. The clinical features of children and adolescents with school refusal. Anadolu Psychiatry J 2009; 10:310-317. 